\title{
Penerapan Pendekatan Contekstual Teaching adnd Learning untuk Meningkatkan Prestasi Belajar Kondisi Fisik Wilayah Indonesia
}

\author{
Mudjiatun $^{(1)}$ \\ ${ }^{1}$ SMP Negeri 2 Ngantru, Tulungagung \\ Email: ${ }^{1}$ mudjiatun@gmail.com
}

\begin{abstract}
ABSTRAK
Berdasarkan hasil observasi yang dilakukan di Kelas VIII A pada waktu pembelajaran IPS diperoleh hasil bahwa Prestasi belajar siswa kurang memuaskan, yaitu dari 33 siswa hanya 11 siswa yang nilainya dapat mencapai KKM atau $>70$, sedangkan 22 siswa lainnya masih belum dapat mencapai KKM atau < 69. Hal ini disebabkan karena guru kurang memberikan penekanan materi yang jelas tentang Kondisi Fisik Wilayah Indonesia tersebut, setelah mem $\neg$ berikan tugas kepada siswu guru meninggalkan ruangan, guru tidak menggunakan strategi. maupun Model yang dapat digunakan untuk mengembangkan kreatif siswa, serta masih banyak siswa yang bermain sendiri pada saat pembelajaran berlangsung. Untuk itu agar dapat mening $\neg$ katkan prestasi belajar siswa dalam menyelesaikan soal tentang Kondisi Fisik Wilayah Indone $\neg$ sia serta untuk tercapainya tujuan pembelajaran perlu diadakan perbaikan pembelajaran dengan menerapkan Model Pembelajaran Contextual Teaching and Learning. Rumusan masalah penelitian ini : (a) Bagaimana penerapan Pendekatan Model pembelajaran CTL (Contextual Teaching and Learning) untuk meningkatkan prestasi belajar siswa dalam materi Kondisi fisik wilayah Indonesia Kelas VIII A SMP Negeri 2 Ngantru Tulungagung ? (b) Apakah penerapan Pendekatan Model pembelajaran CTL (Contextual Teaching and Learning) dapat meningkatkan prestasi belajar siswa dalam materi Kondisi fisik wilayah Indonesia Kelas VIII A SMP Negeri 2 Ngantru Tulungagung? (c) Bagaimana hasil pembelajaran Kondisi fisik wilayah Indonesia dengan menggunakan Pendekatan Model pembelajaran CTL (Contextual Teaching and Learnᄀing) pada siswa Kelas VIII A SMP Negeri 2 Ngantru Tulungagung? Penelitian ini menggunakan jenis penelitian tindakan kelas (PTK). Hasil penelitian menunjukkan bahwa penerapan Model Pembelajaran Contextual Teaching and Learning untuk meningkatkan Prestasi belajar siswa pada materi Kondisi Fisik Wilayah Indonesia siswa Kelas VIII A SMP Negeri 2 Ngantru Tulungagung mempunyai kriteria keberhasilan baik. Hal ini dibuktikan dengan adanya peningkatan Prestasi belajar siswa berdasarkan nilai post test per siklus dengan nilai di atas KKM yaitu persentase pada siklus I $60,6 \%$ dan pada siklus II $87,9 \%$. Simpulan yang diperoleh dari hasil penelitian ini adalah bahwa penerapan pembelajaran Kondisi Fisik Wilayah Indonesia melalui Model Pembelajaran Contextual Teaching and Learning dapat meningkatkan Prestasi belajar siswa Kelas VIII A SMP Negeri 2 Ngantru Tulungagung dan dapat mempermudah siswa dalam menyelesaikan persoalan Kondisi Fisik Wilayah Indonesia. Oleh karena itu guru menggunakan Model Pembelajaran Contextual Teaching and Learning dalam pembelajaran IPS pada materi Kondisi Fisik Wilayah Indonesia agar Prestasi belajar siswa meningkat.
\end{abstract}

Kata kunci: Prestasi belajar, Pembelajaran Contextual Teaching and Learning.

\section{PENDAHULUAN}

Belajar pada hakikatnya adalah perubahan perilaku yang bersikap kognitif, afektif maupun psikomotor melalui pengalaman. Sebab itu pembelajaran haruslah berpusat pada siswa. Hal ini sejalan dengan KTSP yang dilaksanakan di dalam sistem pendidikan nasional di Negara ini. Pembelajaran yang sesuai KTSP menuntut peserta didik sebagai tokoh utamanya dalam semua maia pelajaran, IPS adalah salah satunya.

IPS adalah salah satu pelajaran yang diberikan di jenjang SMP. Oleh karena itu, peningkatan mutu pendidikan khususnya mata pelajaran IPS juga perlu dilakukan. Di samping itu, IPS merupakan pengetahuan yang mempunyai peran sangat besar, 
baik dalam kehidupan sehari-hari maupun dalam menghadapi kemajuan IPTEK sehingga IPS perlu dibekalkan kepada setiap peserta didik sejak SMP.

Secara formal, pembelajaran IPS dibekalkan kepada siswa agar memiliki kemampuan berpikir logis, analitis, sistematis, kritis, dan kreatif, serta bekerjasama. Kompetensi tersebut diberikan agar peserta didik dapat memiliki kemampuan memperoleh, mengelola, dan memanfaatkan informasi untuk memecahkan permasalahan yang dihadapinya. Keberhasilan pembelajaran IPS tersebut tergantung pada siswa dalam proses belajar mengajar, sedangkan keberhasilan siswa tidak hanya tergantung pada sarana dan prasarana pendidikan, serta kurikulumnya. Akan tetapi, Guru dalam proses pem-belajaran juga dapat mempengaruhi peningkatan prestasi belajar IPS siswa, salah satunya dengan penggunaan metode pembelajaran yang tepat oleh Guru sesuai dengan materi yang disampaikan.

Dalam proses pembelajaran di kelas sering timbul masalah yang pada umumnya dialami oleh siswa. Masalah yang dihadapi siswa bersifat unik berbeda satu sama lain. Misalnya masalah dan kesulitan ataupun rendahnya hasil belajar yang dialami siswa pada mata pelajaran IPS bisa terjadi karena berbagai faktor diantaranya. (1) Keterbatasan kemampuan, keadaan, minat dan motivasi diri siswa itu sendiri. (2) Situasi belajar di sekolah atau kelas dan kurangnya sarana dan prasarana. (3) Materi pelajaran yang kurang relevan dengan kebutuhan siswa. (4) Metode mengajar yang kurang bisa dipahami siswa bahkan kurangnya alat peraga dan alat bantu mengajar.

Apalagi mata pelajaran IPS menuntut kemampuan Guru untuk bisa membuat siswa mengerti dan memahami tentang materi yang diajarkan dengan tidak hanya membaca buku dan teori saja melainkan harus disertai contoh, praktek, latihan soal, dan sebagainya, agar siswa memiliki pengetahuan, keterampilan dan bahkan sikap ilmiah yang berujung pada pemerolehan prestasi hasil belajar yang maksimal.

Berdasarkan hasil pengamatan dalam proses belajar mengajar dikelas, keadaan sekolah, dan melalui peninjauan bidang akademik dan non akademik, diperoleh hasil bahwa keadaan SMP Negeri 2 Ngantru khususnya siswa Kelas VIII A tahun ajaran 2015/2016 dalam pelajaran IPS belum menunjukkan hasil belajar sesuai dengan KKM yang ditetapkan terutama pada pembelajaran IPS tentang Kondisi fisik wilayah Indonesia. Padahal, ditinjau dari keadaan fisik sekolah, yaitu ruang Kelas VIII A sudah baik dan sesuai sebagai tempat berlangsungnya proses belajar mengajar. Pengamatan pada proses pembelajaran oleh peneliti dapat disimpulkan bahwa pelaksanaan proses belajar mengajar lah yang belum membuat siswa aktif belajar, sehingga kemampuan siswa belum tergali dengan maksimal.

Tujuan penelitian ini adalah (1) Mendeskripsikan penerapan Pendekatan Model pembelajaran CTL (Contextual Teaching and Learning) untuk meningkat $\neg k a n$ prestasi belajar siswa dalam materi Kondisi fisik wilayah Indonesia Kelas VIII A SMP Negeri 2 Ngantru Tulungagung. (2) Meningkatkan prestasi belajar siswa dalam materi Kondisi fisik wilayah Indonesia melalui Pendekatan Model pembelajaran CTL (Contextual Teaching and Learning) pada Kelas VIII A SMP Negeri 2 Ngantru Tulungagung. (3) Mendeskripsikan hasil pembelajaran Kondisi fisik wilayah Indonesia dengan menggunakan Pendekatan Model pembelajaran CTL (Contextual Teaching and Learn-ing) pada siswa Kelas VIII A SMP Negeri 2 Ngantru Tulungagung.

\section{METODE}

Dalam pelaksanaan Penelitian Perbaikan Pembelajaran ini yang akan menjadi subjek adalah siswa siswi Kelas VIII A SMP Negeri 2 Ngantru Tulungagung, pada semester 1 tahun pelajaran 2015/2016 yang berjumlah 33 siswa terdiri dari 15 laki-laki dan 18 perempuan. Mata pelajaran yang dijadikan subjek penelitian adalah IPS.

Lokasi yang digunakan tempat penelitian adalah ruang Kelas VIII A SMP Negeri 2 Ngantru Tulungagung Tahun Pelajaran 2015/2016. Alasan peneliti melaksanakan penelitian di tem $\neg$ pat tersebut adalah peneliti merupakan salah satu Guru mata pelajaran di sekolah sehingga memudahkan peneliti dalam melaksanakan penelitian serta dapat menghemat waktu dan biaya. Pelaksanan Penelitian Perbaikan 
Pembelajaran dilaksanakan pada semester 1 dalam dua siklus yaitu: Siklus Pertama dilaksanakan pada hari Rabu, 11 November 2015 dan Siklus Kedua dilaksanakan pada hari Rabu, 18 No-vember 2015. Setiap kali pertemuan membutuhkan waktu 80 menit dengan rincian $2 \times 40$ menit.

Dalam kegiatan penelitian, peneliti meminta bantuan teman sejawat untuk mengamati pelaksanaan perbaikan pembelajaran dalam penelitian ini. Hal ini dilakukan agar hasil penelitian lebih objektif dan dapat dipertanggungjawabkan. Observer terdiri atas dua orang Guru yaitu, Ibu Mudjiatun, S. Pd, M. M. Pd dan teman sejawat, yang membantu peneliti dalam merekam proses pembelajaran dengan instrument yang dipilih.

Kegiatan merancang dan melaksanakan perbaikan pembelajaran dengan menerapkan tindakan penelitian kelas akan dilakukan sebanyak 2 siklus, yang dimulai dari refleksi pada sebelum pelaksanaan perbaikan pembelaja $\neg$ ran dimulai. Namun jika setelah siklus ke-II masih belum menunjukkan adanya peningkatan hasil belajar dan pemahaman siswa, maka akan dilanjutkan sampai siklus ke-III.

Berdasarkan hasil pengidentifikasian dan penetapan masalah, peneliti kemudian mengajukan suatu solusi yang berupa penerapan pendekatan CTL yang dapat dimanfaatkan Guru untuk digunakan sebagai metode pengajaran dalam pembelajaran IPS Kelas VIII A SMP Negeri 2 Ngantru Tulungagung.

Penelitian ini dilakukan dengan dua siklus, dimana masing-masing siklus dikenai perlakuan yang sejenis dengan bobot yang beda. Dibuat dua siklus dimaksudkan untuk memperbaiki sistem pengajaran yang dilaksanakan.

Instrumen penelitian adalah alat atau sarana yang digunakan oleh peneliti untuk mengumpulkan data penelitian. Data penelitian yang dimaksud adalah sebuah informasi dari penelitian tindakan kelas ini, yaitu berupa kata-kata, angka-angka, gambar, segala sesuatu yang dapat digunakan untuk menjawab masalah penelitian.

Instrumen yang dikembangkan oleh Guru sebagai peneliti disesuaikan berdasarkan kebutuhan data penelitian itu sendiri. Guru atau peneliti mengidentifikasi dan mempersiapkan berbagai ragam instrument yang diperlukan dalam penelitian tindakan kelas ini. Guru ataupun peneliti mempersiapkan instrument penelitian dengan tepat, tentunya supaya data yang terkumpul dapat lebih bermakna dan bermanfaat bagi kegiatan penelitian.

Adapun ragam instrument penelitian tindakan kelas yang telah dipersiapkan yaitu, Rencana Pelaksaaan Pembelajaran sebagai instrument rencana pelaksanaan tindakan. Lembar observasi Guru sebagai instrument utama pengumpul data proses dan lembar observasi siswa, wawancara, angket dan catatan lapangan sebagai instrument pendukung pengumpul data proses.

Selain itu juga terdapat instrument pengumpul data hasil, yang dapat dikumpulkan dari prestasi belajar berdasarkan soal-soal yang diberikan, serta ketrampilan siswa berdasarkan rubrik yang ada.

Teknik analisis yang digunakan yaitu deskriptif persentase. Data hasil penelitian yang dianalisis meliputi rata-rata kelas, ketuntasan belajar individu dan ketuntasan belajar secara klasikal. Selanjutnya hasil analisis data diperoleh baik secara kualitatif (dengan kata-kata) dan kuantitatif (dengan grafik). Hasil ini diinterprestasikan dan disimpulkan untuk menjawab permasalahan yang ada.

\section{HASIL}

Sebelum melaksanakan proses penelitian, peneliti mengumpulkan data dan informasi tentang subjek penelitian. Data-data yang dikumpulkan antara lain daftar nama siswa Kelas VIII A, daftar nilai ulangan harian IPS tentang Kondisi fisik wilayah Indonesia, hasil wawancara dengan informan yaitu siswa Kelas VIII A SMP Negeri 2 Ngantru Tulungagung,

Dari pengumpulan data, nilai ulangan harian IPS tentang Kondisi fisik wilayah Indonesia, rata-rata nilai yang didapat hanya sebesar 63 . Dari 33 siswa, hanya 11 siswa yang mendapat nilai di atas 70 . Ini berarti hanya $33,3 \%$ siswa yang telah 
mencapai ketuntasan belajar, karena Kriteria Ketuntasan Minimal (KKM) telah ditentukan sebesar 70. (Nama siswa dan nilai bisa dilihat di lampiran).

Rumus rata-rata nilai harian Bahasa Indonesia tentang Kondisi fisik wilayah Indonesia adalah:

$X=\left(\sum X\right) /\left(\sum \sum_{i} N\right)$ Jadi $X=2078 / 33=63$

Nilai $\mathrm{KKM}=70$

Rumus Ketuntasan Individu (prestasi belajar siswa) $=$

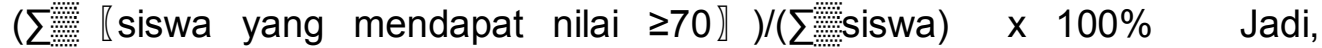
Ketuntasan Individu (prestasi belajar siswa) $=11 / 33 \times 100 \%=33,3 \%$

Analisis soal yang telah dilakukan menunjukkan bahwa kesulitan paling banyak dialami siswa dalam menyelesaikan soal-soal IPS tentang Kondisi fisik wilayah Indonesia.

Berdasarkan kondisi awal di atas, maka akan diterapkan Model Pembelajaran CTL, sehingga siswa Kelas VIII A SMP Negeri 2 Ngantru Tulungagung tahun pelajaran 2015/2016 dapat mengatasi kesulitan belajar IPS tentang Kondisi fisik wilayah Indonesia.

Dari tabel diatas dapat kita lihat bahwa terdapat 2 siswa atau $6.3 \%$ yang mendapat nilai antara 0 - 40, ada 20 siswa atau $60,6 \%$ siswa yang mendapat nilai antara 41 - 69, dan ada 11 siswa atau 33,3\% siswa yang mendapat nilai antara 70 100. Dengan ketentuan nilai KKM 70, maka dapat disimpulkan jika pencapaian prestasi nilai 70 - 100 yang hanya 33,3\% merupakan prestasi yang rendah.

Selain itu, dari proses wawancara diperoleh kesimpulan bahwa siswa kurang berminat dalam mengerjakan soal tentang Kondisi fisik wilayah Indonesia, serta dalam pembelajaran Guru lebih sering menggunakan ceramah sehingga siswa merasa jenuh dan bosan, akibatnya minat siswa untuk belajar IPS terutama pada tentang Kondisi fisik wilayah Indonesia menjadi berkurang sehingga mempengaruhi hasil prestasinya.

Berdasarkan hasil data yang dikumpulkan, dapat dikemukakan dua hal pokok yang perlu diatasi, yaitu menumbuhkan minat siswa untuk belajar IPS dan memahamkan tentang Kondisi fisik wilayah Indonesia dengan cara mengaktifkan siswa dalam kegiatan belajar mengajar dan meningkatkan prestasi belajar siswa dengan menerapkan Model Pembelajaran CTL pada siklus I nanti dengan harapan prestasi belajar siswa dapat meningkat.

Jika pada siklus 1, target indikator pencapaian prestasi belajar masih kurang dari $85 \%$ maka akan dilanjutkan dengan siklus 2 dan seterusnya, hingga target indikator pencapaian peningkatan prestasi belajar siswa pada pelajaran Bahasa Indonesia khususnya pembelajaran IPS tentang Kondisi fisik wilayah Indonesia dapat terpenuhi, yaitu $85 \%$ atau lebih.

\section{Siklus 1}

Pelaksanaan siklus I yang dilaksanakan pada hari Rabu,11 November 2015 di ruang Kelas VIII A SMP Negeri 2 Ngantru Tulungagung pada jam pertama dan kedua. Pertemuan direncanakan berlangsung $2 \times 40$ menit dil $\neg$ aksanakan pada jadwal terstruktur. Proses bela $\neg$ jar mengajar mengacu pada rencana pembelaja $\neg$ ran yang telah dipersiapkan. Pengamatan (observasi) dilaksanakan bersamaan dengan pelaksaaan belajar mengajar. Adapun tahapan-tahapan siklus I adalah sebagai berikut:

Langkah peneliti antar lain adalah menyiapkan instrument penelitian, dan bahan ajar salah satunya Rencana Pelaksanaan Pembelajaran Siklus I materi pelajaran Bahasa Indonesia Kelas VIII A semester 1, dcngan Kompetcnsi Dasar 1.1 Mendeskripsikan kondisi fisik wilayah dan penduduk. (RPP Siklus I dalam lampiran)

Mempersiapkan silabus, materi pelajaran, tugas kelompok atau lembar kegiatan, post test. Feneliti juga menyiapkan lembar evaluasi post test evaluasi digunakan peneliti untuk mengukur sejauh mana kebcrhasilan proses pem-belajaran. Peneliti pun menyiapkan lembar observasi, untuk mengamati proses pembelajaran dan lembar angket untuk mengetahui hasil metode pembelajaran. 
Vol. 1 No. 1, Oktober 2017

Kegiatan diawali dengan menjelaskan tentang metode yang akan digunakan yaitu Model Pembelajaran CTL dan komponen-komponennya kepada siswa. Guru membuka pelajaran dengan mengucapkan salam. Guru memberikan apersepsi tentang Kondisi fisik wilayah Indonesia dengan mengajukan pcrtanyaan "Bagaimanakah letak geograils wilayah Indonesia?"

Setelah itu, siswa dibagi ke da lam 6 (enam) kelompok sesuai absensl setelah itu Guru atau Peneliti memberikan penjelasan tentang tujuan pembelajaran dan garis besar IPS tentang Kondisi fisik wilayah Indonesia.

Setelah siswa bergabung ke dalam kelompoknya masing-masing. Guru atau Peneliti membagi tugas kepada setiap kelompok untuk merangkum kondisi fisik wilayah Indone $\neg$ sia yang dikerjakan bersama dengan kelompoknya masing-masing.

Dalam pelaksanaan kegiatan mengerjakan lembar kerja siswa. Guru memberi bimbingan. Secara berkelompok, siswa berdiskusi dalam menganalisis hubungan letak geografis dengan perubahan musim dan informasi-informasi lainnya. Pelaksanaan percobaan ini sebagai penerapan awal Model Pembelajaran CTL digunakan untuk menguji jawaban sementara)

Setelah kegiatan kelompok selesai, dilanjutkan dengan diskusi kelas yang dipandu oleh Guru untuk membahas hal-hal yang tidak atau belum terselesaikan dalam kegiatan kelompok. Guru secara bergilir mendekati masing-masing kelompok untuk memberikan penguat serta penjelasan sesuatu hal yang belum dipahami oleh siswa (Kegiatan diskusi adalah kegiatan Model Pembelajaran CTL menarik kesimpulan)

Guru atau peneliti membacakan hasil diskusi di depan kelas. Guru berperan sebagai moderator untuk membantu siswa menanggapi hasil presentasi hasil diskusi, atas perintah Guru, kemudian salah satu siswa perwakilan dari masing-masing kelompok melaporkan hasil diskusinya dimuka, siswa yang lain memperhatikan. Guru memberikan ulasan terhadap materi yang belum tersentuh oleh kerja kelompok siswa, serta memberikan ulasan terhadap materi yang belum tersentuh oleh kerja kelompok siswa.

Secara bersama-sama, Guru mengambil simpulan dan mendiskusikannya bersama siswa. Guru memberikan post tes untuk mengukur keberhasilan yang dicapai siswa. (lembar soal dapat dilihat di lampiran). Sehingga bisa dilihat peningkatan prestasi belajarnya.

Kegiatan observasi dilaksanakan saat proses pembelajaran IPS berlangsung. Kegiatan observasi difokuskan pada pelaksanaan pembelajaran. Dalam kegiatan ini, Guru mengamati jalannya pembelajaran.

Pertama-tama Guru memberikan penjelasan, instruksi atau pertanyaan tentang Kondisi fisik wilayah Indonesia.

Kedua, Guru mengamati langkah-langkah kegiatan siswa ketika melaksanakan percobaan, sudah sesuaikah langkah yang ditempuh siswa dengan langkah-langkah yang tertera dalam lembar kegiatan. Hasilnya, masih ada kelompok yang terlihat bingung dalam pelaksanaannya, ada yang kurang teliti, ada pula yang bingung dengan langkah yang harus dilaksanakan.

Ketiga, Guru mengamati keaktifan siswa saat melaksanakan percobaan, ada beberapa siswa yang tidak aktif dalam melaksanakan percobaan, siswa tersebut hanya berdiam diri, seolah-olah tidak mau tahu.

Pengamatan selanjutnya, Guru mengamati bagaimana keaktifan siswa ketika berdiskusi untuk menarik simpulan, ada beberapa siswa yang aktif berargumen dan ada yang berdiam din saja. Pengamatan yang paling akhir adalah bagaimana kesimpulan hasil diskusi siswa, apakah sesuai dengan hasil pelaksanaan percobaan atau tidak. Dari pengamatan yang terakhir ini ada dua kelompok yang belum berani mempresentasikan hasil temuan, dan hanya terdapat 4 (empat) siswa yang mau mengajukan pertanyaan. Hal ini disebabkan, kurangnya petujuk dan bimbingan dari Guru. 
Vol. 1 No. 1, Oktober 2017

Dari uraian di atas dapat disimpulkan hasil observasi dari siklus I antara lain Sebagian besar siswa mengerjakan tugas secara berkelompok dengan antusias Sebagian besar siswa terlibat aktif dalam pembclajaran dengan menggunakan Model Pembelajaran CTL. Sebagian besar siswa sudah memperhatikan penjelasan Guru. Hanya ada 6 siswa yang tidak memperhatikan, mereka justru mengajak bicara dengan teman sebangkunya. Sebagian besar siswa sudah dapat memahami lembar kegiatan dengan baik, hanya terdapat 6 siswa yang masih bertanya pada Guru tentang letak geografis. Baru terdapat sebagian kecil siswa yang ikut ambil bagian dalam diskusi kelompok. Sebagian besar siswa justru saling berbincang dengan teman duduknya. Terdapat 4 (empat) kelompok yang melaksanakan diskusi dengan sungguh-sungguh. Dari 6 (enam) kelompok, baru terdapat 4 (empat) kelompok yang sudah dapat menyelesaikan Lembar Kegiatan dengan tepat waktu. Sedangkan 2 (satu) kelompok yang lain membutuhkan waktu lebih dari 20 menit Dari 6 (enam) kelompok, baru ada 3 (tiga) kelompok yang sudah berani mempresentasikan hasil temuan kelompoknya, sedangkan 3 (dua) kelompok yang lain belum berani. Metode pembelajaran dengan memberikan tugas kepada peserta didik untuk untuk merangkum kondisi fisik wilayah Indonesia yang dikerjakan bersama dengan kelompoknya masing-masing terlihat kurang efektif. Karena banyaknya materi yang harus di rangkum, sehingga waktu yang dialokasikan dalam pembelajaran kurang terlaksana dengan baik. Sewaktu presentasi hasil kelompok dilakukan, hanya terdapat 6 (enam) siswa yang mau mengajukan pertanyaan. Sehing $\neg$ ga dapat disimpulkan jika siswa kurang maksimal dalam menyerap konsep yang diajarkan. Masih ada beberapa siswa yang belum aktif dalam menjawab pertanyaan.

Dalam pelaksanaan pembelajaran, Guru masih menghadapi berbagai kendala, antara lain:Masih ada kelompok yang bingung dalam mengikuti langkahlangkah yang tertera dalam lembar kegiatan. Masih ada beberapa siswa yang belum aktif dalam pelaksanaan percobaan. Ketika pelaksanaan diskusi, ada beberapa siswa yang tidak aktif menyampaikan pendapatnya. Dalam menyimpulkan hasil percobaan, terdapat 2 (dua) kelompok yang malu untuk presentasi, dan hanya terdapat 4 (empat) siswa yang mengajukan pertanyaan. Adapun prosentase hasil observasi dalam pelaksanaan percobaan pada siklus I dapat dilihat dari tabel 3 bawah ini. Perhitungan prosentase keberhasilan siklus I di bawah ini diskusikan juga dengan teman sejawat.

Hasil post test pada siklus pertama dapat menjadi perhitungan persentase peningkatan prestasi belajar siswa. Dengan acuan penilaian tetap berdasarkan nilai KKM yang telah ditetapkan yaitu paling sedikit siswa memperoleh nilai 70 . Adapun rekapitulasi hasil test siklus I adalah sebagai berikut: (nama siswa dan daftar nilai bisa dilihat di lampiran)

Nilai rata-rata hasil post test, dapat dihitung dari :

$X=\left(\sum\right.$ \# $\left.X\right) /\left(\sum\right.$ in N $)$ Jadi $X=2427 / 33=73,5$

Nilai $\mathrm{KKM}=70$

Rumus Ketuntasan Individu (prestasi belajar siswa) =

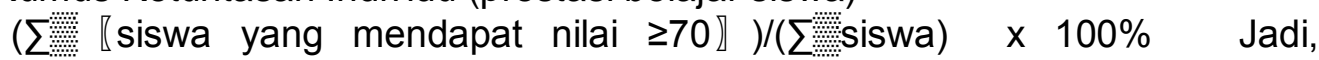
Ketuntasan Individu (prestasi belajar siswa) $=20 / 33 \times 100 \%=60,6 \%$

\section{Siklus II}

Berdasarkan hasil refleksi pada siklus I, disepakati bahwa siklus kedua perlu dilaksanakan. Pelaksanaan siklus II yang dilaksanakan pada hari Rabu, 18 November 2015 di ruang Kelas VIII A SMP Negeri 2 Ngantru Tulungagung pada jam pertama dan kedua. Pertemuan direncanakan berlangsung 2x40 menit dilaksanakan pada jadwal terstruktur. Proses belajar mengajar mengacu pada rencana pembelajaran yang telah dipersiapkan. Pengamatan (observasi) dilaksanakan bersamaan dengan pelaksaaan belajar mengajar. Adapun tahapan-tahapan siklus II adalah sebagai berikut:

Untuk mengatasi hal-hal yang dihadapi dalam pelaksanaan siklus I peneliti melakukan hal-hal antara lain Guru lebih memperhatikan dan mendekati siswa dan kelompok yang memerlukan bimbingan; Guru memberi bimbingan bagi siswa dan 
kelompok yang memerlukan Guru memandu siswa dalam melaksanakan percobaan; Guru mengganti rencana pembelajaran Model Pembelajaran CTL baru yaitu dengan mewajibkan seluruh kelompok untuk membawa Atlas, Guru memilihkan kelompok berdasarkan kelompok pada siklus 1, Karena pada siklus I diketahui masih banyak siswa yang malu untuk maju presentasi dan mengajukan pertanyaan, maka pada siᄀklus II ini Guru memberikan reward kepada siswa yang mau maju presentasi dan aktif dalam diskusi baik bertanya maupun menjawab pertanyaan.

Langkah peneliti antara lain adalah menyiapkan instrument penelitian, dan bahan ajar salah satunya Rencana Pelaksanaan Pembelaja $\neg$ ran Siklus II Mata pelajaran Bahasa Indonesia Kelas VIII A semester 1, dengan Kompetensi Dasar 1.1 Mendeskripsikan kondisi fisik wilayah dan penduduk (RPP Siklus I dalam lampiran)

Mempersiapkan pula silabus, materi pelajaran, tugas kelompok atau lembar kegiatan, post test. Peneliti juga menyiapkan lembar evaluasi post test, evaluasi digunakan peneliti untuk mengukur sejauh mana keberhasilan proses pembelajaran. Peneliti pun menyiapkan lembar observasi, untuk mengamati proses pembelaja $\neg$ ran dan lembar angket untuk mengetahui hasil metode pembelajaran.

Langkah-langkah yang dilakukan Guru dalam pelaksanaan siklus II ini antara lain, kegiatan diawali dengan Guru membuka pelajaran dengan mengucapkan salam; Guru mengulang materi yang lampau yang berkaitan dengan materi yang akan disampaikan sekarang dengan menunjukkan gambar Peta di depan kelas; Memberikan apersepsi, "Gambarlah di papan tulis, pola angin muson di Indonesia!"

Menjelaskan kembali tentang metode ynng akan digunakan yaitu Model Pembelajaran CTL dan komponen-komponennya kepada siswa. Siswa menuju kelompoknya masing-masing, setelah itu Guru atau peneliti memberikan penjelasan lagi tentang tujuan pembelajaran dan garis besar IPS tentang Kondisi fisik wilayah Indonesia.

Setelah siswa bergabung ke dalam kelompoknya masing-masing. Guru membagikan lembar kegiatan yang berisi petunjuk pelaksanaan percobaan untuk penemuan, kemudian menugaskan siswa untuk melaksanakannya (lihat lampiran). Dalam pelaksanaan kegiatan mengerjakan lembar kerja siswa, Guru memberi bimbingan. Siswa melaksanakan kegiatan percobaan sesuai lembar kegiatan. (lihat lampiran).

Dalam satu kelompok terdiri dari 5-6 orang. Siswa berdiskusi untuk menguraikan berbagai kondisi fisik wilayah Indonesia yang terdapat di atlas yang mereka bawa masing-masing.

Pelaksanaan percobaan ini sebagai penerapan kedua dan digunakan untuk menguji jawaban kelemahan siklus I).

Setelah kegiatan kelompok selesai, dilanjutkan dengan diskusi kelas yang dipandu oleh Guru untuk membahas hal-hal yang tidak atau belum terselesaikan dalam kegiatan ke-lompok. Selama siswa berdiskusi, Guru secara bergilir mendekati masing-masing kelompok untuk memberikan penguat serta penjelasan sesuatu hal yang belum dipahami oleh siswa. (Kegiatan diskusi adalah kegiatan Model Pembelajaran CTL menarik kesimpulan)

Guru atau peneliti membacakan hasil diskusi di depan kelas. Guru berperan sebagai moderator untuk membantu siswa menanggapi hasil presentasi hasil diskusi, atas perintah Guru, kemudian salah satu siswa perwakilan dari masing-masing kelompok melaporkan hasil diskusinya dimuka, siswa yang lain memperhatikan. Guru memberikan ulasan terhadap ma $\neg$ teri yang belum tersentuh oleh kerja kelompok siswa, serta memberikan ulasan terhadap materi yang belum tersentuh oleh kerja kelompok siswa. Sebagai perbaikan siklus I, Guru memberikan reward kepada siswa yang aktif dalam diskusi dan presentasi. Dengan iming-iming re $\neg$ ward yang ditawarkan Guru, banyak dari siswa menjadi aktif dalam diskusi dan bertanya atau pun menjawab pertanyaan, bahkan di antara ke $\neg$ lompok mereka saling berebut untuk presentasi di depan kelas. 
Vol. 1 No. 1, Oktober 2017

Secara bersama-sama, Guru mengambil simpulan dan mendiskusikannya bersama siswa. Guru memberikan post tes atau quis untuk mengukur keberhasilan yang dicapai siswa. (lembar soal dapat dilihat di lampiran).

Sama dengan pelaksanaan observasi pada siklus I, kegiatan observasi dilaksanakan saat proses pembelajaran IPS berlangsung. Kegiatan observasi difokuskan pada pelaksanaan pembelajaran.

Pertama, dalam kegiatan ini, Guru mengamati jalannya pembelajaran.

Kedua, Guru mengamati langkah-langkah kegiatan siswa ketika melaksanakan percobaan, sudah sesuaikah langkah yang ditempuh siswa dengan langkah-langkah yang tertera dalam lembar kegiatan. Pada siklus II ini Guru telah memberi bimbingan kepada kelompok-kelompok yang mengalami kesulitan pada siklus I untuk menerapkan langkah-langkah yang terᄀtera dalam lembar kegiatan.

Hasilnya, semua kelompok dapat memahami langkah-langkah pembelajaran dan dapat menjalankan kegiatan sesuai dengan lem $\neg$ bar kegiatan yang tersedia.

Ketiga. Guru mengamati keaktifan siswa saat melaksanakan percobaan, Pada siklus II ini kebanyakan siswa telah aktif dalam mengikuti pelaksanaan percobaan, hanya terdapat 2 siswa yang terlihat mengobrol ataupun berdiam diri.

Pengamatan selanjutnya, Guru mengamati bagaimana keaktifan siswa ketika berdiskusi untuk menarik simpulan, karena mereka ditugaskan untuk menguraikan berbagai kondisi fisik wilayah Indonesia yang terdapat di atlas yang mereka bawa masing-masing, mereka lebih antusias dalam menyambil kesimpulan. Pengamatan yang paling akhir adalah bagaimana kesimpulan hasil diskusi siswa, apakah sesuai dengan hasil pelaksanaan percobaan atau tidak. Dari pengamalan yang terakhir ini, dengan adanya reward yang diberikan oleh Guru, semua kelompok berani mempresentasikan hasil temuannya, dan hanya terdapat 2 siswa saja yang kurang aktif dalam diskusi.

Dari uraian di atas dapat disimpulkan hasil observasi dari siklus II antara lain : Sebagian besar siswa mengerjakan tugas secara berkelompok dengan antusias. Sebagian besar siswa terlibat aktif dalam pembelajaran dengan menggunakan Model Pembelajaran CTL dengan cara siklus II. Hampir semua siswa sudah memperhatikan penjelasan Guru. Hanya ada 2 siswa yang tidak memperhatikan, mereka justru mengajak bicara dengan teman sebangkunya ataupun melamun.

Dengan adanya reward, terdapat sebagian besar siswa yang ikut ambil bagian dalam diskusi kelompok. Sebagian kecil siswa masing tampak saling berbincang dengan teman duduknya ataupun melamun. Diskusi dilakukan dengan baik. 6 (enam) kelompok yang terbagi, mereka sudah dapat menyelesaikan Lembar Kegiatan dengan tepat waktu. Siswa yang terlihat lemah pada siklus I, lebih banyak mendapat perhatian dan bimbingan dari Guru.

Dengan adanya reward, 5 (lima) kelompok sudah berani mempresentasikan hasil temuan kelompoknya. Mereka tampak de-tail dalam mempresentasikan hasil temuannya. Metode pelaksanan pembelajaran Model Pembelajaran CTL dengan Kondisi fisik wilayah Indonesia menunjukkan hasil yang efektif dan hasil yang memuaskan.

Sewaktu presentasi hasil kelompok dilakukan, dengan adanya reward, hampir semua siswa mengajukan pertanyaan, hanya terdapat 2 siswa yang masih malu mengajukan pertanyaan. Sehingga dapat disimpulkan bahwa penerapan Model Pembelajaran CTL siklus II ini maksimal dalam menyerap konsep yang diajarkan. Hasil post test menjukkan prestasi belajar siswa pun meningkat.

Dalam pelaksanaan proses pembelajaran, Guru telah melaksanakan perbaikan dari siklus I, siswa sudah mengalami kemajuan dan pelaksanaan pun telah berjalan baik. Namun Guru menemukan masalah baru dalam pelaksa $n$ naan siklus II, yaitu Beberapa siswa masih kesulitan dalam menguraikan berbagai kondisi fisik wilayah Indonesia yang terdapat di atlas yang mereka bawa masing-masing. Masih terdapat 2 siswa yang malu dalam presentasi dan kurang aktif dalam diskusi kelompok. 
Vol. 1 No. 1, Oktober 2017

Adapun prosentase hasil observasi dalam pelaksanaan percobaan pada siklus II dapat dilihat dari tabel bawah ini. Perhitungan prosentase keberhasilan siklus II di bawah ini diskusikan juga dengan teman sejawat.

Hasil post test pada siklus kedua dapat menjadi perhitungan persentase peningkatan prestasi belajar siswa. Dengan acuan penilaian tetap berdasarkan nilai KKM yang telah ditetapkan yaitu paling sedikit siswa memperoleh nilai 70 . Adapun rekapitulasi hasil test siklus II adalah sebagai berikut: (nama siswa dan daftar nilai bisa dilihat di lampiran)

Nilai rata-rata hasil post test, dapat dihitung dari:

$X=\left(\sum \sum_{i} X\right) /\left(\sum\right.$ in $\left.N\right)$ Jadi $X=2753 / 33=83,4$

Nilai KKM $=70$

Rumus Ketuntasan Individu (prestasi belajar siswa) =

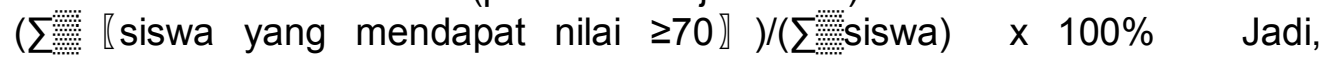
Ketuntasan Individu (prestasi belajar siswa) $=29 / 33 \times 100 \%=87,9 \%$

\section{PEMBAHASAN}

\section{Siklus 1}

Masing kurang dari indikator pencapaian siklus I sebesar $85 \%$ atau lebih. Maka dilanjutkan percobaan pembelajaran dengan Model Pembelajaran CTL pada siklus II.

Tabel berikut adalah daftar frekuensi nilai post test siklus I IPS tentang Kondisi fisik wilayah Indonesia siswa Kelas VIII A SMP Negeri 2 Ngantru Tulungagung.

Dari tabel diatas dapat kita lihat terdapat 13 siswa atau 39,4\% yang mendapat nilai antara 41 - 69, dan 20 siswa atau 60,6\% yang mendapat nilai antara $70-100$. Dengan ketentuan nilai KKM 70, dapat disimpulkan jika pencapaian prestasi nilai 70 100 , maka prestasi belajar siswa telah meningkat dari 33,3\% menjadi $60,6 \%$. Namun karena belum mencapai target indikator pencapaian siklus I sebesar $85 \%$ atau lebih, maka akan dilanjutkan ke Siklus II.

Selain itu, dari proses wawancara diperoleh kesimpulan bahwa beberapa siswa men-jadi bersemangat dalam belajar IPS, karena pelaksanaan kegiatan belajar IPS dengan Model Pembelajaran CTL ini dilaksanakan dengan langsung secara mandiri oleh siswa, dan melaksanakan kegiatan bersama kelompok sehingga lebih ringan. Meskipun masih terdapat kendala-kendala seperti yang telah diuraikan dalam laporan observasi.

Dari hasil post test, 20 nilai siswa telah sesuai KKM atau diatas nilai 70 . Sedangkan 13 siswa dari 33 siswa belum berhasil. Karena nilai siswa berada di bawah 70.

\section{Siklus 2}

Telah mencapai indikator pencapaian siklus II sebesar $85 \%$ atau lebih. Maka tidak perlu dilanjutkan percobaan pembelajaran dengan Model Pembelajaran CTL pada siklus III.

Tabel berikut adalah daftar frekuensi nilai post test siklus II IPS tentang Kondisi fisik wilayah Indonesia siswa Kelas VIII A SMP Negeri 2 Ngantru Tulungagung setelah pembelajaran menggunakan Model Pembelajaran CTL siklus II, dengan nilai minimal KKM sebe-sar 70:

Dari tabel diatas dapat kita lihat terdapat 4 siswa atau 12,1\% yang mendapat nilai antara 41 - 69, dan 29 siswa atau 87,9\% yang mendapat nilai antara $70-100$. Dengan ketentuan nilai KKM 70, dapat disimpulkan jika pencapaian prestasi nilai 70 100 , maka prestasi belajar siswa telah meningkat dari $60,6 \%$ menjadi $87,9 \%$. Dengan $87,9 \%$ maka telah tercapai indikator pencapaian siklus II sebesar yang $85 \%$ atau lebih, maka tidak perlu dilanjutkan ke Siklus III.

Selain itu, dari proses wawancara diperoleh kesimpulan bahwa bcberapa siswa menjadi bersemangat dalam belajar IPS, karena pclaksanaan kegiataii belajar 
Vol. 1 No. 1, Oktober 2017

IPS yang Bermodel Pcmbclajaran CTL ini dilaksanakan dengan rnandiru menvcnangkan, serta melaksanakan kegiatan bersama kelompok menjadikan mereka lebih rileks dan ringan dalam mengerjakan lapomn kegiatan. Meskipun masih terdapat kendala-kendala seperti yang telah diuraikan dalam laporan observasi.

Dari hasil post test, 29 nilai siswa telah sesuai KKM atau diatas nilai 70 . Sedangkan 4 siswa dari 33 siswa belum berhasil. Karena nilai siswa berada di bawah 70.

Berdasarkan hasil pelaksanaan pada siklus I, II dapat dinyatakan bahwa terjadi peningkatan kualitas pembelajaran yang tampak dan perolehan hasil evaluasi dan keaktifan siswa.

Dari label 4.2 dan gambar 4.2 siklus 1 hasil observasi menunjukkan, prosentase keberhasilan kelengkapan menyiapkan alat dan bahan percobaan $68 \%$, prosentase keruntutan langkah-langkah yang ditempuh dalam pelaksanaan percobaan $70 \%$, prosentase keaktifan siswa da $\neg$ lam melaksanakan kegiatan percobaan $68 \%$, prosentase keaktifan siswa dalam mengutarakan pendapat saat berdiskusi $75 \%$ dan prosentase hasil penarikan kesimpulan akhir sesuai percobaan $70 \%$.

Berdasarkan tabel 4.5 dan gambar 4.4 siklus II hasil observasi menunjukkan, prosentase keberhasilan metode kelengkapan menyiapkan alat dan bahan percobaan siswa yang disiapkan $85 \%$, prosentase kenmtutan langkah-langkah yang ditempuh dalam pelaksanaan percobaan $90 \%$, prosentase keaktifan siswa dalam melaksanakan kegiatan percobaan $80 \%$, prosentase keaktifan siswa dalam mengutarakan pen $\neg$ dapat saat berdiskusi $90 \%$ dan prosentase hasil penarikan kesimpulan akhir sesuai percobaan $86 \%$.

Dari daftar nilai (lihat lampiran) dapat kita lihat adanya prosentase kenaikan nilai IPS mulai dan kondisi awal pra tindakan, diketahui baru 11 siswa atau $33,3 \%$ yang mengalami ketuntasan belajar dan mendapatkan nilai sesuai dengan KKM. Hasil evaluasi siklus I menunjukkan baru 20 siswa atau 60,0\% yang mengalami ketuntasan belajar dan mendapat nilai sama dengan atau di atas KKM yaitu 70. Hal itu menunjuk $\neg k a n$ bahwa pelaksanaan siklus I belum mencapai keberhasilan, karena indikator pencapaian adalah sebesar $85 \%$ atau lebih. Siklus II menunjukkan ada 29 siswa atau 87,9\% dari 33 siswa yang 11 mengalami ketuntasan belajar. Sehingga peneliti menyimpulkan bahwa pada siklus II ini peneliti telah mencapai keberhasilan dari penelitian tindakan kelas yang telah dilakukan.

Ketika peneliti melaksanakan siklus I, peneliti mengalami berbagai kendala antara lain beberapa siswa tampak bingung dalam menentukan Kondisi fisik wilayah Indonesia. Masih ada kelompok yang bingung dalam mengikuti langkah-langkah yang tertera dalam lembar 1 kegiatan. Masih ada beberapa siswa yang belum aktif dalam pelaksanaan percobaan. Ketika peneliti melaksanakan sikius I, peneliti mengalami berbagai kendala antara lain beberapa siswa tampak bingung dalam menentukan Kondisi fisik wilayah Indonesia. Masih ada kelompok yang bingung dalam mengikuti langkah-langkah yang tertera dalam lembar kegiatan. Masih ada beberapa siswa yang belum aktif dalam pelaksanaan pcrcobaan. Ketika pelaksanaan diskusi ada beberapa siswa yang tidak aktif menyampaikan pendapatnya. Dalam menyimpulkan hasil pcrcobaan, terdapat 4 (tiga) kelompok yang main untuk presentasi, dan hanya terdapat 4 (empat) siswa yang mengajukan pertanyaan.

Peneliti kemudian melaksanakan siklus II sebagai perbaikan siklus I, sebelum pelaksanaan siklus II ini peneliti mengganti rencana pembelajaran Model Pembelajaran CTL baru yaitu dengan mewajibkan kelompok membawa atlas Indonesia dan menguraikan berbagai kondisi fisik wilayah Indonesia yang terdapat di atlas yang mereka bawa masing-masing. Dalam pelaksanaan percobaan, peneliti senantiasa memberi bimbingan untuk siswanya dalam melaksanakan langkah-langkah sesuai lembar kegiatan. Peneliti pun memberi bimbingan siswa saat berdiskusi untuk menarik kesimpulan. Dengan adanya motivasi guru berupa reward, siswa telah terlihat aktif dalam kegiatan pembelajaran dalam melaksanakan percobaan, presentasi di depan kelas dan berdiskusi menarik kesimpulan. Meskipun ada kendala yai-tu ada beberapa 
siswa yang masih kesulitan dalam menguraikan berbagai kondisi fisik wilayah Indonesia yang tcrdapat di atlas yang mereka bawa masing masing sehingga suasana menjadi gaduh, namun dengan hasil prestasi belajar yang dicapai dapat disimpulkan bahwa penelitian tindakan kelas dari siklus II ini telah berhasil.

\section{KESIMPULAN}

Berdasarkan hasil penelitian tindakan kelas yang telah dilaksanakan dalam 2 siklus dengan menerapkan Model Pembelajaran CTL dalam pembelajaran IPS pada siswa Kelas VIII A SMP Negeri 2 Ngantru Tulungagung, dapat dibuat kesimpulan sebagai berikut: Penerapan Pendekatan Model Pembelajaran CTL dapat meningkatkan prestasi belajar IPS siswa Kelas VIII A SMP Negeri 2 Ngantru Tulungagung.

Hal ini dilihat dari prosentase kenaikan nilai IPS Kelas VIII A dari pra siklus, siklus 1 sampai Siklus II. Pada pra siklus, sisvva yang mendapat nilai minimal 70 ada 11 siswa atau $33,3 \%$, pada siklus I siswa yang mendapat nilai minimal 70 ada 20 siswa atau $60,6 \%$, pada si-klus II sisvva yang mendapat niiai minimal 70 ada 29 siswa atau $87,9 \%$ dari 33 siswa. Dari pra siklus kemudian dilaksanakan siklus I prestasi siswa mengalami prosentase kenaikan 27,3\%. Dan dari siklus I kemudian dilaksanakan siklus II prestasi siswa mengalami prosentase kenaikan 27,3\%.

Penerapan pembelajaran dan prosedur dalam penelitian ini didasarkan pada pembelajaran dengan menerapkan Model Pembelajaran CTL dalam pelaksanaan proses pembelajaran IPS. Model yang dipakai dalam penelitian tindakan kelas ini adalah model siklus, adapun prosedur penelitiannya terdiri dari 2 siklus. Siklus I dilᄀaksanakan pada hari Rabu, 11 November 2015, siklus II dilaksanakan hari Rabu, 18 November 2015.

Dalam setiap pelaksanaan siklus terdiri dari 4 (empat) tahapan, yaitu perencanaan tindakan, pelaksanaan, observasi, dan refleksi, kegiatan ini dilaksanakan berdaur ulang.

Sebelum melaksanakan tindakan dalam tahap siklus, perlu perencanaan. Perencanaan ini memperhatikan setiap perubahan yang dicapai pada siklus sebelumnya terutama pada setiap tindakan yang dapat meningkatkan prestasi belajar siswa. Hal ini didasarkan pada analisis pcrkembangan dari pra siklus, siklus I sampai siklus II.

Berdasarkan kriteria temuan dan pembahasan hasil penelitian seperti yang diuraikan pada bab IV, maka penelitian ini dapat digunakan peneliti untuk membantu guru dalam menghadapi permasalahan yang sejenis. Disamping itu, perlu penelitian lanjut tentang upaya guru untuk mempertahankan atau menjaga dan meningkatkan prestasi belajar siswa. Pembelajaran dengan menggunakan Model Pembelajaran CTL pada hakikatnya dapat digunakan dan dikembangkan oleh guru yang menghadapi permasalahan yang sejenis, teruta $\neg$ ma untuk mengatasi masalah peningkatan pres $\neg$ tasi belajar siswa, yang pada umumnya dimiliki oleh sebagian besar siswa.

\section{SARAN}

Berdasarkan hasil penelitian, maka ada beberapa saran yang dapat dipergunakan sebagai bahan pertimbangan dan sebagai bahan uraian penutup penelitian tindakan kelas ini, antara lain: Bagi Guru, Hendaknya mempersiapkan secara cermat perangkat pendukung pembelajaran dan fasilitas belajar yang diperlukan, karena sangat mempengaruhi efektivitas dan efisiensi pembelajaran yang pada akhirnya berpengaruh pada proses dan prestasi belajar IPS siswa. Guru juga harus memahami dan memvariasikan metode yang sesuai materi yang dapat digunakan dalam proses pembelajaran, sehingga siswa tidak merasa bosan. Bagi Siswa, Hendaknya ikut berperan aktif dalam proses pembelajaran, selalu mengerjakan tugas-tugas yang diberikan guru dan meningkatkan usaha belajar sehingga dapat memperoleh prestasi yang diharapkan. Bagi Sekolah, Hendaknya mengupayakan pengadaan berbagai media pembelajaran IPS, baik bantuan maupun swadaya 
sekolah, sehingga lebih menunjang dalam penanaman konsep-konsep IPS secara lebih nyata sekaligus mcningkatkan aktivitas belaiar siswa. Bagi Orang Tua, Peran serta orang tua dalam meningkatkan prestasi siswa sangat diperlukan, apapun usaha guru tidak akan berhasil secara optimal apabila tidak ada bimbingan orang tua di rumah, masukan, informasi tentang kemajuan dan kekurangan siswa yang bersangkutan. Oleh karena peran serta orang tua sangatlah diperlukan guna menunjang keberhasilan pendidikan anak, untuk itu kerjasama dan jalinan kekeluargaan antara orang tua dan sekolah harus selalu dibina.

\section{DAFTAR RUJUKAN}

Abin Syamsuddin Makmun. 2003. Psikologi Pendidikan. Bandung: PT Rosda Karya Remaja, Bandung

Arifin. Zaenal. 2009. Evaluasi Pembelajaran. Bandung: Remaja Rosdakarya.

Arikunto, Suharsimi, dkk. 2006. Penelitian Tindakan Kelas. Jakarta: Bumi Aksara

Bhuchori M. 1992. Psikologi Pendidikan 3. Bandung: Jeanmars

Depdiknas. 2006. Kurikulum 2006 Mata Pelajaran Bahasa Indonesia. Jakarta: Departemen Pendidikan Nasional.

Fudyartanto, Ki RBS. 2002. Psikologi Pendidikan dengan Pendekatan Baru. Yogyakarta: Global Pustaka IImu.

Gulo, W. 2002. Strategi Belajar Mengajar. Jakarta: Grasindo.

Hayinah. 1992. Masalah Belajar. Malang: IKIP Negri Malang,

Kasim, Melany. 2008. Model Pembelajaran IPS, (Online), Http: // Wodrpres. Com. (diagses 20 April 2009)

Koentjaraningrat, et.al. 1999. Manusia dan Kebudayaan Indonesia. Jakarta: Djambatan.

Kuraesin, Nunung. 2003. Model Pembelajaran CTL. Bandung: Dinas Pendidikan Provinsi Jawa Barat

Muhibbin Syah. 2003. Psikologi Belajar. Jakarta: PT. Raja Grafmdo Persada

Nana Sudjana \& Ibrahim. 1989. Penelitian dan Penilaian Pendidikan. Bandung : Sinar Baru.

Oemar Hamalik. 2003. Kurikulum dan Pembelajaran. Jakarta : Bumi Aksara.

Oemar Hamalik. 2004. Proses Belajar Mengajar. Jakarta : Bumi Aksara

S. Nasution. 1996. Azas-azas Mengajar, Bandung: Tarsito

Slavin, R. E. 1994. Educational Psychology Theory Into Practices. 4th ed. Boston: Ally and Bacon Publishers

Sudarmi, Sri dan Waluyo, Galeri Pengetahuan Sosial Terpadu 2: Untuk SMPMTS Kelas VIII A. Maryanto (ed.). Jakarta: Pusat Perbukuan, Departemen Pendidikan Nasional, 2008.

Suganda, Elia. 2003. Konsep Dasar dan Penerapan Pembelajaran Contextual Teaching and Learning (CTL) Mala Pelajaran Bahasa Indonesia. Bandung : Dinas Pendidikan Provinsi Jawa Barat 